\title{
Winning and Losing in the Modern Era: Identity, Mobilisation, and Empowerment in Southeast Asia
}

\section{Meredith L. Weiss}

\begin{abstract}
In Southeast Asia as elsewhere, shifts in global, regional, and domestic politics and economies benefit some and disadvantage others. Overall, those individuals and groups defined by their subordinated position in the emerging political economy are at a disadvantage. Moreover, the decline of ideology, particularly with the seemingly hegemonic advance of neoliberalism, has limited space for challenge along those lines. Rather than assume, however, that it is merely the wealthiest 'one per cent' who are advantaged and empowered in this evolving system, we can weigh what resources and alliances are available to whom. Members of newly-formed categories may benefit from the shifting tides, regardless of class or structural position, for instance given their alignment with prevailing norms or frames, or their access to new media and transnational advocacy networks. Some of those most disadvantaged by the shifting economic context, on the other hand, may be doubly disempowered, as they face added hurdles to identity-building and collective action. This article explores new regimes of domination and resistance from below, focusing on why particular collective identities gain salience at particular moments and what determines which movements or claims take off or fail to thrive.
\end{abstract}

KEYWORDS: Southeast Asia, mobilisation, identity, labour, LGBT

\section{INTRODUCTION}

$\mathbf{W} \begin{aligned} & \text { ODEs OF POLITICAL ACTIVISM are sticky, but hardly static. With economic } \\ & \text { development, global integration, new technologies, and new political }\end{aligned}$ leaders, patterns of mobilisation and state-society interaction change. While such changes have been dramatic globally since the 1980s, Southeast Asia as a region has been especially buffeted, particularly since the Asian financial crisis of 1997-1998, but starting earlier, as the Cold War thawed, authoritarian regimes faltered, populism gained purchase, and neoliberal frameworks seeped ever wider and deeper.

The implications of these changes for aspiring activists are mixed. As in any era, certain categories and agendas are privileged, either per local norms or in their access to transnational allies. Human rights claims gain leverage now, for instance, if tethered to a globally-resonant master frame; environmental activism 
has enhanced clout, however curbed as it confronts neoliberal goals; Islamists and their opponents alike are newly alert to the power and potential of a global ummah; 'queer' mobilisation offers urban, educated, financially-flush gays rubrics and models, perhaps at the expense of less-urbane, non-normative others. In the meantime, changing demographics - from in- and out-migration, as well as shifts in birth rates and life expectancies, settlement patterns, and education - complicate mobilisation in all sorts of ways. The end result is an altered roster of likely winners and losers, chasing new stakes as well as old.

The key categories of the old politics have slipped from their dais: workers, of whom a paltry and diminishing proportion are now unionised; ${ }^{1}$ students, however much greater their number than ever before $;{ }^{2}$ and even the military, no longer assured political clout in much of the region. Moreover, new mobilisational resources, particularly media platforms, change the scope and emphasis of coalition-building and engagement, as does the ever-growing potential for transnationalisation of movement politics. The old forms have not disappeared, but they have been overlaid with new collective identities and tactics.

To some extent, these shifts mirror what new social movement (NSM) theories predict: that collective action - expressive as well as instrumental in its goals and likely oriented around (newly) constructed categories - will develop at a historically-specific point, but be poorly explained by economic reductionism. These theories differentiate more or less sharply between 'old' and 'new' identities and attendant interests (for an overview see Buechler 1995). However, my focus here is somewhat different: not just the rise of identity politics in light of newly-developing economic orders, but how these inflect our assessment of the polity, beyond the industrialised democracies on which NSM theories are premised. Feedback processes between macro-level socio-political change and meso- or micro-level mobilisation are manifest in the sorts of identity categories that thrive or wither, resources available or scarce, and tactics celebrated or discarded. What complicates investigation is both the limited visible success of these mobilisations and their overlapping, often transient or semi-occluded nature.

\footnotetext{
${ }^{1}$ Data, particularly trend data, are hard to find. One account offers union density (ratio of union membership to total employment) figures of 26.8 per cent for the Philippines (2002), 18.5 per cent for Singapore (2006), 17.5 per cent for Malaysia (2000), 14 per cent for Indonesia (2005), 3.3 per cent for Thailand (2006), and 1 per cent for Cambodia (2006) (Hall-Jones 2007). Distribution by sector, however, varies significantly: density is highest in private services in Malaysia, but in manufacturing in the Philippines and Singapore (with the rate in construction also high in the latter); of the three, only in Malaysia are agricultural workers unionised to any significant extent. The ratio of those covered by collective agreements to total employment (as of 2003) for these three states plus Thailand ranges from 0.5 per cent in Thailand to 12 per cent in Singapore (Lawrence and Ishikawa 2005: Appendix 1, Tables A2, B1). Organising among migrant workers remains limited.

${ }^{2}$ In 1970, the average proportion of the relevant age cohort enrolled in higher education in East Asia and the Pacific was 3 per cent; the world average was 9 per cent. By 2005, both these proportions stood at 24 per cent, and within Southeast Asia, exceeded that rate in the Philippines, Malaysia, Thailand, and Singapore (Weiss et al. 2012: Table 1).
} 
Indeed, any lens is unavoidably biased: while a strike is visible to all, subcultural machinations may be apparent only to those either in the know or on the lookout. My goal is thus not a comprehensive catalogue of activism, but to trace and analyse possible trends to begin to make sense of what the evolving roster of collective actors and menu of tactics means for political engagement, agency, and further political change in Southeast Asia. For leverage, I focus my analysis on archetypical 'old' and 'new' social movements: labour and lesbian, gay, bisexual, transgendered (LGBT) activism, respectively.

I focus on Southeast Asia as a set of states guided by broadly similar postcolonial state-building challenges and more recent neoliberal frames, but differentiated in important ways by factors usually deemed salient to patterns of mobilisation and political empowerment: government institutions, levels of economic development, and religion and cultural norms. For purposes of a more tight comparison, I foreground the historically and culturally closely-entwined maritime states of Malaysia, Singapore, Indonesia, and the Philippines: two electoral authoritarian regimes, two democracies; two Muslim-majority states; two with important and protracted authoritarian interregnums; one high income, two upper-middle income, and one lower-middle income; two recently decentralised; two with ongoing violent insurgencies. ${ }^{3}$ After a brief overview, I start where mobilisation begins (and sometimes ends), with collective identity, then turn to the interlinked domains of resources and tactics, before essaying a synthesis.

\section{Mapping The TerRitory}

A combination of selective repression, structural shifts, and ideational flows goes far in accounting for changes in the relative strength of specific state and social forces in Southeast Asia. However, prevailing explanations leave important gaps. Fundamental to any conceptualisation of civil society is the state, as contact, as foil, and often as opponent. State repression in particular interacts with strategies and foci of protest. Unwanted state attention, institutional rejoinders, or measures to channel inputs may be expected to nudge activists toward new niches; the relative threat states, in turn, feel will largely dictate their level and direction of effort in these endeavours. As Vince Boudreau (2004: 28) explains, repression "rewrites" cultural patterns, such that "subsequent oppositional cultures may prolong and reproduce repression's influence". Those legacies compound the effects of subsequent structural and ideological change and suggest the need to keep the state in view, even when assessing activism on the ground.

Writing in the same broad vein as Boudreau, Eva-Lotta Hedman (2001) turns the lens decidedly more on social forces than the state. She looks to the

${ }^{3}$ I exclude Brunei for its lack of substantial mobilisation of any kind (beyond, for instance, A. M. Azahari's failed rebellion in the 1960s) and Timor-Leste for its newness as a sovereign state. 
combined effect of the nature of the regime, constellation of classes, legacies of the left, and institutions of religion on mobilisational efforts in the Philippines, Thailand, Malaysia, and Indonesia since the 1970s. Differences along these four dimensions, she argues, help to explain variations in state-society relations and in processes of reform across these four states, notwithstanding similarities in historical experiences, development trajectories, and discursive frames. While Hedman, too, focuses on broad patterns rather than fine gradations and presents political subjectivity as comparatively bounded in its manifestations, emergence of the sort of variations in mobilisation she details might be expected to continue.

Many of the country case studies in Alagappa's (2004) comprehensive survey of Asian civil societies delve further into processes Boudreau and Hedman both suggest, but tend toward a structural lens in tracing an ongoing permeability between civil and political society. These case studies focus largely on politics at a more institutional level than at the level of "participatory citizenship" for emergent, stigmatised, or otherwise marginal identities - those categories that challenge "the collective "we" underlying the state as it now exists (Hobson 2003: 3) or that take advantage of new resources or allies to make otherwiseunlikely claims. Even Rodan and Jayasuriya (2009), in noting the need to burrow below such an institutional level to understand Asian authoritarianism, still take a basically structural approach, looking to the social forces capitalism births, then frustrates, for the source of authoritarian resilience: they home in more on society than the state, and especially the impacts of cross-class alliances. ${ }^{4}$ However important for understanding the distribution and character of political systems in the region, these accounts focus on a stratum less germane to the incessant, largely self-directed reorganising and redistribution of agency as regimes continue to mutate. My concern here - unlike, for instance, Boudreau's is not so much with state-menacing social revolutionaries, but with smaller-scale, endemic attempts to carve out a space for identity and action. I thus aim to trace how comparatively recent changes to state, economy, and transnational context translate within civil society, particularly in light of new modes of control and resistance.

Moreover, I share Rodan and Jayasuriya's concern for the ways in which capitalist (and one might specify, neoliberal) development moulds not just economic ownership and control, but also "the way in which power and authority are exercised to constrain and/or enable certain forms of political organization to function" (Rodan and Jayasuriya 2009: 25). However, the power to which they

\footnotetext{
${ }^{4}$ Rodan and Jayasuriya acknowledge the rise of issues beyond workplace ones (social justice and environmental degradation, for instance), but frame these as fundamentally middle-class interests and/or too politically fragmented to be potent, given their genesis in tensions of capitalism. This lens is not theirs alone. Eva Bellin, for example, explains that the 'social forces' touted in extant theories of democratic transition are "specifically social classes", motivated most importantly by material interests (Bellin 2000: 176-177, emphasis in original).
} 
refer is that of formal politics, and however fungible organisational forms, the identities behind them represent the usual stable. Class identities clearly do remain important and have not been entirely displaced, but a striking feature of contemporary mobilisation is the roster of categories now in play: class permeates identities, interests, and strategies in myriad ways, but mobilisation along the lines of alternate identities is not reducible to class. While capital and labour still spar to dominate the playing field, not all those on the field are playing the same game. And since it is in the nature of authoritarianism that any autonomous identity may be coded a threat, I focus here on the more democratic states of the region, where that right to be is more likely to have been won.

Lastly, my focus is less on the macro parameters of civil society, as for Alagappa, than in the specific, changing content and configuration of identities and claims within that space - not so much with, for instance, the persistence or vulnerability of authoritarianism as with patterns of collective identification and empowerment under that regime. More specifically: while "everyday forms of resistance" (Scott 1985) are useful, ubiquitous, and near-irrepressible, what I explore here is not individual-level catharsis - since engagement may well be on an individual level - but collective mobilisation in the face of changing odds.

\section{Collective Identity}

Political party Ang Ladlad's '5 bid for registration in the Philippines in 2009 met with unusual opposition. Citing both the Bible and the Qur'an, the Elections Commission rejected the request. The Supreme Court soon overturned that decision on equal protections grounds. ${ }^{6}$ What so roiled the Elections Commission was Ladlad's premise: it is the world's first LGBT political party. As such, this party represents in some ways the cutting edge of Southeast Asian activism - not for its 'queer' orientation per se, but for representing a collective identity both new to formal Filipino politics and often deemed the "quintessential identity movement" (Bernstein 1997: 532). Class offers limited leverage on this collective identity - in the Philippines, for instance, transgender hairdressers join with urban gay professionals in LGBT mobilisation - nor can its engagement be read as seriously threatening state elites. Ladlad's goals are clearly limited and tied to a particular collective identity rather than social revolutionary. Yet its development carries real import, in acknowledging and facilitating mobilisation around a salient identity not reducible to class, gender, ethnicity, or other conventional categories.

\footnotetext{
${ }^{5}$ The party dropped the 'Ang' two years later.

${ }^{6}$ Ang Ladlad LGBT Party v Commission on Elections, G.R. No. 190582, 8 April 2010, decision. Available at: http://sc.judiciary.gov.ph/jurisprudence/2010/april2010/190582.htm (accessed on 13 November 2011).
} 
Collective identity refers to "an individual's cognitive, moral, and emotional connection with a broader community, category, practice, or institution" (Polletta and Jasper 2001: 285). Never static, collective identity is best conceptualised as interactive, shared, and persistently mutable (Melucci 1995: 43-45). The relevant 'we' for political mobilisation thus requires not only specification, but continual re-delineation - a process Alberto Melucci dubs identization (1995: 51). Mobilisation around that identity requires also a sense of collective agency, for instance McAdam's notion of "cognitive liberation" in which "oppression is collectively defined as both unjust and subject to change" (McAdam 1999: 34, emphasis in the original). As individual actors come to feel part of a politically meaningful 'we' and to believe that collective action by that 'we' could be effective, we might expect patterns of collective mobilisation to shift accordingly.

In the past the primary, often overlapping, identity categories around which collective action has been staged in Southeast Asia have been class/economic sector and (intertwined with that) ideology (especially communism and liberalism), undergraduate status, religion, and gender (specifically, women). The heyday of each varied: class and ideology loomed large in the 1930s-50s, for instance, whereas student movements surged in the 1960s-70s, and gender gained salience around the 1990s. That roster of key categories has changed since the 1980s-90s. No longer is the collective identity of 'student' so politically potent, for instance; communists can claim little ground outside Vietnam and Laos; gender as an organising category is no longer limited to women or presumptive heterosexuality; and advocates for human rights have coalesced around emergent issues.

A review of media coverage of protest events in Indonesia, the Philippines, Malaysia, and Singapore in 1970, 1990, and 2010 suggests these trends are clear, if not entirely consistent. ${ }^{7}$ Across the four states, protest events (rallies, marches, etc.) tended to be very large - into the tens of thousands in all but Singapore - and centred most commonly around students (in the Philippines, also the non-student political left) in 1970. Their primary antagonist was the state itself, including for corruption, inadequate or wrongly-targeted socioeconomic development, curbs on civil liberties, and tolerance of neo-imperialism. Such events tapered back dramatically by 1990, although still with significant labour actions in all except Singapore (but taking aim at producers rather than state policies in Malaysia) as well as large-scale secessionist mobilisation in Indonesia and substantial rallies against US bases in the Philippines.

2010 saw a surge of protest events overall in the region compared with 1990, but on a much smaller scale, often centred around differently-defined identities,

\footnotetext{
${ }^{7}$ The analysis coded for 'protest', 'demonstration', 'strike', and related terms in the Far Eastern Economic Review and New York Times for 1970 and 1990, and the New York Times, Straits Times, and New Straits Times for 2010. The objective was to track trends in protest magnitude, incidence, composition, and objective - at least among protests prominent media deemed 'newsworthy' - rather than to offer a precise count of episodes.
} 
and less frequently taking the state as their target - for instance, activism among Hindus and against Christians in Malaysia, for animal rights in Singapore, against Malaysians' mistreatment of migrant workers in Indonesia, and against specific employers in the Philippines. (Protest actions not reported in the media surveyed - for instance, mid-2010 Islamist vigilante attacks against sexuality and gender rights advocates in Indonesia - fit within the same pattern, but suggest the vagaries of mainstream media attention.) Violent state repression is less a factor now than previously, given the nature of these challenges, and some actions have worked through formal state structures - for instance, a group of Malaysian students who sued to challenge a law barring their political engagement in 2010, or Ladlad in the Philippines. That said, intermittent mass protests and/or ones that specifically take on the state - for instance, immense rallies for election reform in Malaysia in 2011-12 (not captured in the fixed-interval media survey above) have not only bucked the trend toward smaller, narrowly-focused actions, but also incurred aggressive crackdowns.

Only some of the categories prevalent today represent cells in equivalent, society-wide taxonomies (e.g., in the way that all individuals have a class position, and any class position is presumed equally salient to the individuals it subsumes; sexuality, for instance, tends to lack relevance as an identity category for those who match the norm). Labour has lost much, though not all, of its primacy as a broadly relevant collective actor, as have the grand ideological camps of Cold War and anti-authoritarian struggles. Peasant rebellion seems obsolete, even if diffuse and varied forms of rural resistance, focused more on asserting agency and getting by than subverting the state, persist (Caouette and Turner 2009). This framing is not to suggest a zero-sum game - that making room for gays shuts out workers - but describes a shift, perceptible but never absolute, in the locus and relative balance of activist energies. Consideration first of an 'old' movement, labour, as it stands today, then of a 'new' movement, LGBT activism, will help to clarify how the scope and aims of mobilisation have changed and the ways in which collective identity features.

\section{Labour Mobilisation: Persistent but Changed}

A structural position and class identity as 'worker' remains a basis for mobilisation in Southeast Asia, but less comprehensively or independently than might have been imagined or experienced in the past. That shift does not reflect complacency with gains secured; working class mobilisation still makes sense. But when workers mobilise in today's Southeast Asia, it is not with any reasonable expectation of re-tooling the political or economic contours of the state. Neoliberalism has won that battle; these struggles focus on securing marginally better protections within a fixed framework. The ideology and praxis of neoliberal development require repealing those regulations that protect workers (and hence 
might nudge labour costs upward) and clearing the way for a new slate of "technologies of control" in granting primacy to market forces (Nevins and Peluso 2008: 9).

However, workers have fought back. May Day 2012, for instance, saw protests across Asia centred around calls for higher wages and job security. The largest crowds were in Indonesia, where an estimated 161,000 workers joined rallies nationwide. In impoverished Timor-Leste, over eighty were arrested in Dili from among around five hundred demonstrators, while thousands of protesters in Manila pilloried Philippines president Benigno Aquino III as a stooge of foreign capital. ${ }^{8}$ Those protests had precedents. Just a month before, demonstrations led by Indonesian unions and students had secured at least a temporary reprieve from a hike in fuel prices, following strikes since late 2011 - some of them successful - for better wages. ${ }^{9}$ Five years earlier, too, the 250 -union Federation of the All-Indonesia Workers' Union (Konfederasi Serikat Pekerja Seluruh Indonesia, KSPSI) threatened a general strike and led mass rallies across Java over proposed amendments to the national labour law, designed to boost foreign investment by rolling back labour protections. The government capitulated, although as the global financial crisis deepened, declining production and increasing unemployment kept the law in limbo. ${ }^{10}$ Workers thus exercised agency - but defensively, narrowly instrumentally, and only to a point.

Meanwhile, proposed amendments to Malaysia’s Employment Act likewise drew significant protests; at least one thousand picketed in Penang in 2011 (about the same number that rallied in 2007 to demand a minimum wage), with smaller crowds in over a dozen other locations. ${ }^{11}$ Both mainstream and independent media, however, granted these events far less coverage than they did the banning of a much smaller-scale LGBT rights festival (to which we return below) that same week. ${ }^{12}$ Indeed, reporting on the Malaysian labour protests, however objectively noteworthy they were, was comparatively buried. A thousand-strong truckers'strike in early May 2012, too, forced the Port Klang Authority to rollback its fees, yet was massively overshadowed by a contemporaneous demonstration for electoral reform. ${ }^{13}$ Such media disinterest illustrates how little political

\footnotetext{
${ }^{8}$ Indonesia stages Asia’s biggest May Day rally, JakartaGlobe, 1 May 2012.

${ }^{9}$ Demonstrators block toll road to protest fuel price hike, Antara News, 30 March 2012; Dessy Sagita, Fight over Indonesia's fuel hikes not over, JakartaGlobe, 1 April 2012.

${ }^{10}$ Bill Guerin, Labor pains in Indonesia, Asia Times Online, 26 April 2006; Gross and Connor 2009.

${ }^{11}$ Anil Netto, Live-Spirited nationwide protests against labour law amendments, anilnetto.com, 3 Nov. 2011. Available at: http://anilnetto.com/democracy/workers-rights/live-spirited-protestsagainst-employment-act-amendments/ (accessed 4 November 2011).

${ }^{12}$ Elsewhere, queer mobilisation takes heteronormativity to include a full syndrome of ways-thingsare, embracing labour, housing rights, militarism, and more (for instance, the US-based Pride at Work coalition). Such mobilisation is not currently apparent Malaysia, apart from expressions of support across 'progressive' organisations, and despite efforts to discredit activists for other causes who also endorse LGBT rights (for instance, 'LGBT claim' will not disrupt Bersih rally, Malaysiakini, 24 April 2012).

${ }^{13}$ PKA orders fee cut after 'unprecedented' strike, Malaysiakini 4 May 2012.
} 
salience the category labour now enjoys in Malaysia (even if such 'enjoyment' in the past also entailed coercive suppression). Indeed, while after years of entreaties from the Malaysian Trades Union Congress (MTUC), Prime Minister Najib announced Malaysia’s first-ever minimum wage on May Day 2012, the gesture came mere days after a harsh crackdown on those protests for electoral reform - so this concession to labour could hardly be read as proof of civil society's newfound potency. ${ }^{14}$

Meanwhile, not only have endemic processes of industrial restructuring complicated 'traditional' labour mobilisation but ongoing and extensive labour migration continues to disrupt patterns of socio-political community. Migration does create new possibilities for transnational mobilisation, yet class mobilisation still tends to begin at home, at the level of the nation-state. Given how much more nationally-bound politics is than economics, migration tends to result not in global solidarity, but in partial citizenship across multiple locations, with uncertain protections and limited empowerment (Parreñas 2001). That atomisation is all the more likely when workers find themselves pitted against potential rivals in lower-wage states; workers will see little cause in class-based global solidarity when their mobility still lags behind that of capital (cf. Enloe 2004: 54-56). Southeast Asian trade unions have done little to support migrant workers, despite commitments since at least the mid-1990s to do so; unions in workers' home countries generally have limited access or power transnationally, and those in host countries face hurdles ranging from language barriers, to migrants' hesitancy in contacting them, to lack of resources and state or employer restrictions on union recruitment (Wickramasekera 2002: 30-32). Most workers, then, experience migration more as subjects than as citizens.

Women, for instance, are particularly sought across a range of feminised and low-end occupational sectors. While their wages are lower, and women are central to early, labour-intensive stages of export-oriented industrialisation, weak unions, policies conducive to women's work outside the home, and gendered discourses surrounding work (e.g., on men as unreliable and women as docile and diligent) matter, too, to the feminisation of particular industries (Caraway 2007). Patterns of labour migration magnify these effects. Such factors as low birth rates and aging populations in host countries, coupled with declining state-provided social services, prestige considerations among bettereducated and more affluent citizens, and gendered notions of women as caregivers sustain a market for migrant women's work, both within and beyond the region. ${ }^{15}$ Specific policies in sending states, particularly the Philippines, to

\footnotetext{
${ }^{14}$ Liz Gooch, Malaysia enacts minimum wage, New York Times, 1 May 2012. Not only were the announced minima lower than the MTUC had requested, but the announcement was widely seen as a political ploy, with elections looming.

${ }^{15}$ Around two million women work as migrant domestic workers in Southeast Asia, mostly from elsewhere in the region or neighbouring states such as Sri Lanka. Malaysia recruits about 60,000 domestic workers per year from Indonesia; Singapore imports 8-9,000 per month, mostly from
} 
facilitate labour export further those trends, while simultaneously disciplining women to fit market expectations (Lin 2001: 38; Rodriguez 2008). Migrant women's chances of political engagement and efficacy - already likely suppressed by gender and socioeconomic status - are far less in these host countries than at home.

Transnational advocacy networks go some way toward raising and addressing concerns over male and female migrant workers' human rights, particularly when backed by local civil societal organisations (Piper and Uhlin 2002). Yet such advocacy, even when available, is not the same as full empowerment qua independent citizens. And perversely, when the odds seem otherwise stacked against singleaxis, working class mobilisation, such intervention may prioritise a 'worker' (or in some targeted campaigns, 'sex worker') identity above other relevant categories - which may not have been the case for the same individual back home.

\section{LGBT ACtivism: IDENTITIES IN FLUX}

With the expansion of civil society and in line with global patterns, an increasing share of Southeast Asian activism centres not on structural categories, but issues: human rights, environment, sexuality. A quick scan of the core struggles of recent years reveals newly-mobilised collective actors - either freshly-coalesced or simply more salient than previously - but limited capacity to effect political change. Whether that mobilisation is thus 'worthwhile' begs another metric. For some of these identity categories, inefficacy is likely to translate into failure even to achieve or sustain faith in the value of collective action, beyond awareness of collective grievance. For others, recognition of that collective identity as valid and shared is itself a goal, yielding affective rewards. And yet other categories - for instance, an efflorescence of religious activism around Islam, Buddhism, Christianity, and Hinduism across the region - may provoke new policies, ideological frames, or repression. Of course, not all collective identities are grounds for mobilisation, regardless, nor are these struggles fully independent of one another.

A recent spate of mobilisation around sexuality and homophobia demonstrates both the emergence and the fraught course of new identity categories. The Philippines' Ladlad, discussed above, offers one example: after years of autonomous mobilisation, informed by local socio-political contexts and conceptions of gender and sexuality, but tied in with transnational advocacy networks, LGBT Filipinos added a dimension of institutional mobilisation to their heretofore non-institutional repertoire. While a Ladlad representative has yet to secure election, the party's campaign bolstered visibility for 'LGBT' as an identity category, suggested a degree of legitimacy for that category, and articulated

the Philippines and Indonesia. These and other low-wage, unskilled foreign workers are subject to specific host-country restrictions and enjoy limited social mobility (Kaur 2007). 
concrete policy goals for the community, making clear the potential for framebridging and coalitional politics. Yet while more institutionalised in the Philippines than elsewhere in the region, the category 'LGBT' or cognates thereof has taken root region-wide.

For instance, Malaysian activists have held a program of events called Seksualiti Merdeka (Sexuality Independence) annually since 2008. ${ }^{16}$ While LGBT mobilisation is less organisationally rooted in Malaysia than in the Philippines, Thailand, or Indonesia, it has been percolating under the radar, fostered by influences ranging from the imperative of HIV-prevention outreach efforts among men who have sex with men, which has allowed for the protection of non-discriminatory 'free spaces' for community-building (Weiss 2006), to supportive global discourses and organisations. In 2011, however, Seksualiti Merdeka came under attack. On one level, the attacks were the latest manifestation of tightly-wound Islamist sensitivities: by asserting a right to be so identified, LGBTs, regardless of religion, posed an affront to the religion of the majority of Malaysia's citizens. To strengthen such claims, Muslim religious leaders insisted that homosexuality violated the tenets of all religions.

On the other hand, the timing and leadership of the homophobic frenzy in which homosexuality was branded a threat to national security and officials mulled criminalising mere 'support' for homosexuality under syariah ${ }^{17}$ suggested Seksualiti Merdeka offered a new stage for an old communal contest. Leading the charge was attention-seeking Malay-rights group, Perkasa. Backing a racialist reading of events is the fact that while plenty of those involved with or supporting Seksualiti Merdeka were themselves Malay-Muslim, the main targets - people like organiser Pang Khee Teik and lawyer/activist Ambiga Sreenevasan, who was slated to officiate - were not. ${ }^{18}$ (Also, the leader of the Malaysian Chinese Association, a component party in the ruling coalition, vouched for the right to practice whatever sexuality one chose in private. ${ }^{19}$ ) At the time, too, elections were thought to be imminent. The furore over Seksualiti Merdeka offered a convenient way to divert attention from the usual scandals and economic woes: it fit the standard script sufficiently well not to be taken entirely at face value as being about a new identity category, at least from an antagonist's perspective, while the fact that the attack came from 'society' rather than the state obscured the 'wag the dog' dimension. All the same, the kerfuffle did backhandedly acknowledge that there is a self-identified, newly-political 'LGBT' category

\footnotetext{
${ }^{16}$ See: http://www.seksualitimerdeka.org. Initially timed to coincide with national Merdeka (Independence Day) celebrations, the programme mirrors a similar initiative in Singapore that began in 2005, the IndigNation festival (see: http://indignationsg.wordpress.com/).

${ }^{17}$ Malaysia [sic] states eye harsher laws for Muslim gays, Asiaone.com, 11 November 2011.

${ }^{18}$ Underscoring the communal bedrock to the attacks on Seksualiti Merdeka: Marina Mahathir, the Malay-Muslim daughter of long-time prime minister Mahathir Mohamad, suffered no penalty for officiating in 2009. Melissa Chi, Malay group wants Ambiga cast out for Seksualiti link, Malaysian Insider, 6 November 2011.

${ }^{19}$ Chua: sexual preference a private decision as long as it harms no one, Star, 9 November 2011.
} 
in Malaysia, even as it eroded whatever confidence members of that category might have in the value of further mobilisation.

In Indonesia, too, sexuality rights advocates have been organising increasingly actively since the 1980s, including under pioneering LGBT organisation GAYa Nusantara, launched in Surabaya in 1987 (succeeding Lambda Indonesia, established in Solo five years earlier), ${ }^{20}$ as well as transgender-specific and other counterparts. As in the Philippines, the key vehicles for mobilisation crosscut other cleavages (class and region, for instance) and aligned themselves with transnational counterparts. As in Malaysia, this identity-based movement has attracted vitriol disproportionate to its reach or impacts. Violent attacks, framed as Islamist, on AIDS and LGBT activists began amidst Indonesia’s political transition in 1999 (Boellstroff 2004; Oetomo 2001); in 2008, vigilantes from several Islamic organisations forced a regional conference of the International Lesbian, Gay, Bisexual, Transgender and Intersex Association (ILGA), hosted by GAYa Nusantara, to a sudden halt, then subsequently stormed a training session on transgender rights. ${ }^{21}$ Here, too, mobilisation was clearly at least significantly directed internally, at community-building and self-help, rather than targeting the state. That elites (some of them self-appointed) still deemed the category 'LGBT' such a threat may both raise its profile and make collective action seem more risky than worthwhile.

This emerging new slate of collective identities would seem to lend itself well to coalitional politics: many groups' relevant claims may be cast in terms of a master frame of 'human rights', even if doing so undercuts their specificity and requires difficult compromise on aims that are not shared. Indeed, the aforementioned transgender rights training was cosponsored by Indonesia's National Commission for Human Rights. Furthermore, circumventing deep-seated clientelist networks as in the Philippines or Indonesia, or transcending the hurdles to competition in illiberal Malaysia or Singapore requires working in coalition, to an extent rarely the case in more pluralist, competitive contexts. The new efflorescence of categories suggests ways to erode obdurate regimes of political control for instance, as Singaporean voters assess opposition parties' positions across a range of niche issues, including LGBT rights. ${ }^{22}$

All these states have seen new coalitional politics, and yet often at a shallow level, without crossing, for instance, ascriptive ethno-religious lines. In part, that limitation reflects the tactics and tools on which activists have relied. Online 'new media', for instance, by dint of their open access and space for low-stakes,

\footnotetext{
${ }^{20}$ Perjalanan sejarah waria, gay dan lesbian, GAYa Nusantara. Available at: http://gayanusantara.or. id/index3.html (accessed 2 October 2013).

${ }^{21}$ Sylvia Tan, Islamic protestors force evacuation of ILGA conference participants in Surabaya, Fridae.com, 26 March; Liang 2010.

${ }^{22}$ See, for instance, People Like Us, 27 Feb. 2011 (http://www.plu.sg/society/?p=223) or the Facebook group, Singaporeans Coming Together for GE 2016 (https://www.facebook.com/groups/ sct2016/; both sites accessed 3 September 2012).
} 
sometimes anonymous participation, favour networks with perhaps a less coherent focus, less firm identity, and less ability to sustain engagement than more organically, incrementally forged alternatives might have enjoyed - and yet those same tools may allow activists unprecedented ability to transcend previously-insurmountable group boundaries at all. It is the very imperviousness of those boundaries, crystallised in the parties and other channels of 'normal politics', which have pressed would-be liberalisers to seek alternative mobilisational modes. To see this shift, we turn now to the changing strategic repertoire of activism.

\section{Resources and Tactics}

While any given venue has its characteristic protest types, those repertoires inevitably shift over time. In Southeast Asia, both identity shifts and official restrictions or suppression accelerate such adaptations. As Boudreau (2004) details, state strategies of attack feed back into activists' strategies of mobilisation; campaigns today bear the scars of past contention.

Largely gone in these Southeast Asian states are the days of the industrial strike (consider Singapore in the 1930s-50s), the boycott (Malaysia's hartal of the 1940s-60s), and the roadblock (despite its resurrection in Bangkok's redyellow battles since 2006). As a review of media coverage seems to confirm, even organised marches are less frequent and widespread than they were, for instance, among students of the 1960s and 1970s, and critical journalism is elusive at best in mainstream publications across much of the region. More common today are (as elsewhere) campaigns conducted virtually over Facebook and YouTube, email and texting (and their progeny, tweeting), urban occupations (e.g., sporadic episodes in Bangkok and Kuala Lumpur since the mid-2000s) as well as more cat-and-mouse street protests, and electoral campaigns across a wider range of states and local constituencies. Most of these campaigns, with the obvious exception of Thailand's essentially social-revolutionary 'colour wars', have been narrowly framed; even Malaysian protests for electoral reform, discussed below, enumerated a finite set of precise policy goals. For instance, among the most energetic campaigns in Singapore in 2010 was a Facebook-based protest, which developed into a small demonstration, against high rates for subscription packages for viewing the World Cup; that same year, over 50,000 Indonesians joined a successful online campaign to relocate a statue of Obama.

That said, some tactics remain intact: elections as spectacle persist (Chua 2007) for instance, and broad coalitions still adopt strategies ranging from petitions and letters of protest to the occasional mass rally. Moreover, activists rely on the state in new ways: from developing broadband networks, to sustaining the intra- and inter-state human flows that give rise to so many contemporary 
claims. Just as the roster of mobilised collective identities has not altogether transformed, the array of tactics, too, has shifted balance without being overturned. Yet with the preponderance of mobilisation via regime-established channels, conducted in a 'virtual' (and imperfectly accessible) space, or reliant on broad, shallow coalitions, transformative impact seems unlikely.

To some extent, emergent identity categories may pursue novel or individually-distinctive ends. All social movements rely on identity for empowerment: to foster the belief that collective action is possible and worth pursuing, regardless of the specific expressive and instrumental goals at stake. So, for instance, LGBT activists may seek to convince the broader public that "we are just like you" and hence legitimate, or to stress their difference, presenting a radical critique of prevailing norms (Bernstein 2008: 278-290; Phelan 1997). That collective self-presentation affects how 'LGBT' fits in amongst the pantheon of extant categories.

The grand narratives of states and societies - of the rise and fall of the left, the ebb and flow of Islamist forces, even the surge of advocacy-oriented NGOs (the foci of Boudreau, Hedman, and others) - tend to miss this level of analysis: the moments at which individuals regroup under new (or new to them) collective identities, perhaps to mobilise at least in part toward ends orthogonal to the state. I suggest that the shift in protest repertoires across insular Southeast Asia since the 1970s-90s (tipping points vary by state) represents not merely the consolidation of particular dichotomies of regime-civil society power, nor a generic enervation of the left and/or rise of Islamists, but a shift in focus. The result of petitions, blogging, even disaggregated work stoppages cannot be expected to be a reordering of elites or renegotiation of bases of governance, but at best, incremental gains, with identity itself a chief arena for contention.

But while these struggles appear from a bird's-eye view as minor squabbles along the margins, from the ground, they represent efforts at self-definition and empowerment in a new, otherwise often disempowering political and economic order, operating across multiple planes of contention. With specification and mobilisation of new collective identities come the celebration and pursuit of attendant new interests, however narrowly delineated, in a way no individual person could singly manage and when other pathways to agency seem increasingly attenuated. Critically, too, their late-breaking rise and expansion in the public arena grants these 'new' identities space for creativity and alliances, and the agency to avoid replicating the problems associated with the 'old' politics of class and nation.

Perhaps the most important front for exploring such shifts, given its simultaneous function as resource and tactic, is the arena of 'new media'. Understood as movement resources or platforms, these media, many of them online, reconfigure the relative endowments of categories of activists. While internet access remains uneven, it is high and rising across the region. For instance, as of July 2011, Indonesia led the region in Facebook access with almost 39 million users (representing still a relatively modest 16 per cent of the overall population); 
the Philippines had over 25 million (of a population of 102 million); Malaysia, over 11 million (of 29 million); and Singapore, 2.5 million (over half the total population). ${ }^{23}$ While educated, urban youths are everywhere most 'wired', ubiquitous cybercafés, like Indonesia’s warnet (Lim 2003: 242), expand coverage. Moreover, just as cheap text messaging made the mobile-phone a valuable weapon of the weak, smartphones are rapidly democratising access to the internet by reducing reliance on predominantly urban broadband networks.

Seeing in internet-based social media a low-cost, widely-accessible platform and one which allows a degree of anonymity to temper fear of reprisal - activists have mobilised in new ways online. Consider, for instance, two recent campaigns in Malaysia. The Hindu Rights Action Force, HINDRAF, which challenged the endemic marginalisation and mistreatment of Indian Malaysians, could gain the force it did among a geographically-scattered and justifiably anxious constituency, deploying the identity 'Hindu' in heretofore-unprecedented ways, due to prior mobilisation online (Rathina Pandi 2011). Even more innovative is the Coalition for Clean and Fair Elections, better known as Bersih. Launched initially ahead of the 2008 elections, Bersih used the virtual format of Facebook to establish a sense of collective identity and community, as well as a plan for on-the-ground mobilisation for the 2013 elections. The campaign successfully mobilised tens of thousands of Malaysians who joined rallies in Kuala Lumpur in 2011 and 2012, supplemented by sympathy protests elsewhere in Malaysia and overseas, coordinated through blogs, news sites, Facebook, and Twitter. ${ }^{24}$

The Bersih protests were more convincingly cross-cutting than any other political campaign in recent Malaysian history, drawing participants from across ethnic, religious, and class lines. The protests remained a largely urban phenomenon, given both the main rallies' venue and the still-predominantly urban 'netizenry'. Moreover, the online media that help to spur engagement still mirror linguistic silos to at least some extent, limiting the mingling likely even online; the obduracy of existing categories complicates the development of new collective identities. ${ }^{25}$ The collective identity around which Bersih mobilised, though citizens concerned with free elections - bypassed partisanship and communalism to a noteworthy extent, however temporally and substantively bounded its claims.

Notwithstanding the importance of internet-based new media as a resource for mobilisation, resources alone are not sufficient. Yet another newly-energised LGBT movement, this time in Singapore, had mobilised largely under the radar,

\footnotetext{
${ }^{23}$ Lim Yung Hui, Facebook in Asia: more than 150 million users but slowing growth in quarter 2 2011, GreyReview, 1 July 2011; population data from the CIA's The World Factbook (https:// www.cia.gov/library/publications/the-world-factbook/rankorder/2119rank.html).

${ }^{24}$ Considering just one of these platforms: over 19,000 tweeted that day about the rally in July 2011. Natasja Sheriff, Malaysia's 'silent' awakening. The Nation (New York), 17 August 2011.

${ }^{25} \mathrm{~A}$ speculative mapping of Malaysian blogs reveals two distinct clusters: BG, Malaysia's blogosphere: can you map the social effect of Malaysia’s Chinese schools? Economist, 29 May 2010. Available at: http://www.economist.com/blogs/babbage/2010/03/malaysias_blogosphere/.
} 
substantially through online channels, since at least the 1990s, its chief goal mere recognition (Heng 2001). Over time, at least some within the community developed both 'catness' (a sense of shared identity and solidarity) and 'netness' (dense interpersonal networks), in Tilly's (1978) terms, making mobilisation theoretically more likely, particularly with the added leverage of organisational resources.

Yet what prompted this collective more publicly to deploy its identity for instrumental ends were exogenous spurs: an official pronouncement in 2003 that gay and lesbian Singaporeans were thenceforth permitted even in sensitive positions in the civil service, so long as they 'came out' (Weiss 2005); a review of Singapore's penal code, including provisions against sodomy, in $2007 ; ;^{26}$ and a radical Christian takeover of Singapore's most prominent feminist organisation in 2008. In this last case, a group of women from an evangelical Anglican church (themselves representing a newly-germane mobilisational category), convinced that the Association of Women for Action and Research (AWARE) had become a hotbed of pro-lesbian and -gay activity, evidence to the contrary notwithstanding, staged a coup, winning most seats on AWARE's executive committee. Not just feminists broadly, but Singaporean LGBTs specifically, rallied around AWARE at an immense, raucous general membership meeting (Chong 2011).

The AWARE contest highlighted the extent of development of "small 'p' political activities and political subject formation" in the realm of "cultural politics" in Singapore (Chua 2011: 17). In this case, what sparked deployment of that emergent LGBT identity was not so much a political opportunity, as in the earlier pair of episodes, but an opposing movement's parry (Weiss 2013), which itself intrinsically granted the substance of that collective identity. Put differently, active opposition to the LGBT mobilisation posed 'identity as goal' as accomplished: recognition (and even respect) had been achieved, which is itself a form of empowerment (Hobson 2003). Yet the tactics LGBT rights activists chose in each instance acknowledged both Singapore's technocratic political culture and the community's own tenuous status: circulating petitions, cajoling parliamentary champions, organising meetings, publishing to blogs and Facebook pages, and crafting fundamentally 'educative' events such as the pro-love-for-all Pink Dot events. $^{27}$

Which brings us back to the Philippines' Ladlad, the LGBT political party. The party itself emerged from a coalition of around 150 LGBT groups nationwide. Starting from particular segments - its component groups' networks, a large and well-organised mass of tens of thousands of bakla (loosely, transgender) stylists, web-savvy youth, and others - Ladlad strategists aimed to build a web of support. The party could capitalise, too, on new institutional openings in the polity: the party list system, which allowed voters to cast an additional vote for

\footnotetext{
${ }^{26}$ See: http://www.repeal377A.com/.

${ }^{27}$ Several thousand gay and straight Singaporeans, all clad in pink, come together once a year to make a human 'dot' in a downtown public park. See: http://pinkdot.sg/.
} 
Ladlad, while still supporting a major party. ${ }^{28}$ Even had Ladlad won a seat, the accomplishment would hardly have signalled systemic change in the offing, yet the initiative embodies the sort of meso-level, identity-oriented mobilisation on which at least some level of empowerment, even for the structurally disadvantaged, may rest. So while on the one hand choosing the least transgressive of strategies - running for election - Ladlad did so as a new sort of collective, pursuing a new institutional niche, and relying on innovative networking seeded from a bevy of allies.

Indeed, no new movement emerges onto an empty field. Part of what characterises contemporary mobilisation is its rapid mutability, interactivity, and multiplicity - artefacts of the types of identities and claims at stake, as well as of the tools available. Furthermore, not only are identities layered, frames borrowed or extended, and strategies substantially modular, but movements develop in conversation with each other, whether just aware of the wider field or actively engaging, physically and/or ideologically. Movement and countermovement shape their claims, discourse, frames, and strategies through a process of mutual constitution (Fetner 2008: 120). Stimulating so many different claimants' recourse to the internet, for instance, now is the assumption of an audience, both of supporters and of antagonists; the tool itself may determine the boundaries of the 'we' that forms. Mobilisation may take on the character of the 'flash mob' (itself also a potential tool), in which activists count on rapid informational flows, near-instantaneous responses, and cross-cutting receptivity, instead of deep understanding of or socialisation to support these claims and their claimants. Struggles previously in the shadows may abruptly seize their moment of fame. While some flame out just as quickly, their sudden visibility may gain other movements the allies and genuinely interested audiences (beyond the mass of momentary 'friends') needed to press those struggles forward.

Such a pattern is hardly triumphal; the deck remains stacked. Finding a community or claiming an audience online, for instance, requires not just literacy (in both a general and technological sense), but access to the internet. Low-risk, identity-building tactics - meetings, public forums, and the like - privilege those in cities or usefully clustered. All these modes are substantially discursive, taking for granted fluency in a shared language. Those at the bottom of the socioeconomic heap, particularly when geographically scattered, remain the least likely to develop solidaristic communities, to shift from shared identity to cognitive liberation, or to mobilise in ways specific to their own felt interests, if at all not just due to greater preoccupation with basic needs, but for lack of opportunity. Yet even here, abetted at times by cross-class allies (viz., Singapore's

\footnotetext{
${ }^{28}$ Among other sources: Sanders 2010; Khalel, Ang Ladlad: Senate queer politics, Hush and Listen (blog), posted 13 February 2007. Available at: http://khalelian.blogspot.com/2007/02/its-officialang-ladlad-national.html (accessed 13 Nov. 2011); personal communication with Patricio Abinales, 13 November 2011.
} 
Transient Workers Count Too initiative, ${ }^{29}$ which targets migrant labour), identity building and mobilisation may develop in new ways. Specifically, these efforts may invoke class, but are fundamentally about more than class, dwelling instead at established or evolving intersections, or calling meaningfully upon identities (gender, ethnicity, moral values) that sidestep class altogether.

Clearly, activism still can and does occur using 'old' forms and on the basis of 'old' identities, but the landscape has changed from the scene Hedman or Rodan and Jayasuriya describe. Economic position lacks especial or necessary primacy today as a basis or explanation for much of the mobilisation most salient to individuals' efforts to enhance their situation, even if class identity, like other identities, as well as economic grievances (cronyism, elitism) may still be grounds for important mobilisation. Claims for cultural and economic justice intertwine: workers want both material rewards and dignity, for instance, just as LGBT individuals want not just recognition in its purest sense, but also specific rights and protections. What we have is, as Hobson describes broadly of recognition struggles, a "dynamic interplay between claims to alter maldistribution and challenges to the devaluation of members of a group based on their identities" (Hobson 2003: 1). New patterns and processes of identity formation, yielding categories that make new claims in new ways, are part and parcel of shifting socioeconomic realities and modes of empowerment, even if never the whole story.

\section{Taking Stock}

Southeast Asia's activist terrain is part of a broader socio-political landscape. The instigators of the rise of these new identities and new tactics may be found in wider political and economic developments, from democratisation to everdeeper neoliberal penetration, which limits states' will and ability to prioritise or address certain claims. In Fraser's elegant formulation, "Once the hegemonic grammar of political contestation, the language of distribution is less salient today ... at precisely the moment when an aggressively expanding capitalism is exacerbating economic inequality" (Fraser 2003: 32-33). This cultural turn represents a new mobilisational stage in a manifestly, incorrigibly unequal world. A fair accounting of the impacts of these environmental changes, then - and of the real quality, scope, and durability of democracy - must take stock of the winners and losers: who is emboldened and who pushed to the margins as the stakes, the players, and the tools at hand evolve.

These recent developments may appear merely local manifestations of a global shift toward new social movements (NSMs), or more affective, identitybased forms of mobilisation. Habermas contends, "the new conflicts are not sparked by problems of distribution, but concern the grammar of the forms of

${ }^{29}$ See: http://twc2.org.sg/. 
life" (Habermas 1981: 33, emphasis in the original). This critique is unconvincing. For one thing, the demarcation between 'new' and 'old' movements is hazy at best; all social movements start from a collective identity, and none truly eschews instrumental objectives (Bernstein 2008: 277). For another, the impetus behind these new patterns is not so much a post-industrial yearning to regain a lost sense of emancipated self via non-institutional protest, as NSM theory supposes (Kriesi et al. 1995: xvii-xxi), but fundamentally structural and importantly transnational. Even when identity-based mobilisation is a significantly middle-class phenomenon, it need not be premised upon or related to that class status. Claims about sexual rights, for instance, may be most trenchant when articulated by the most resource-strapped and vulnerable, who may, in the process, come to reassess the polity and their chances in it. But these claims do importantly signal resistance against regimes of governance preoccupied with policing identity itself - with defining and maintaining political subjectivity as a national 'we' - and with restricting scope for collective action along unsanctioned lines. Were workers to identify across borders, for instance, that identity would implicitly challenge the saliency of the state, even if the identity thus invoked achieved little of material substance.

Shifts in structures of domination, from local communities and colonial powers, to independent states, to multinational corporations and alliances, however layered or gradual, yield shifts in patterns of subordination and, hence, resistance. The map of spaces protected and valued (university campuses, for instance) has been jumbled - and changes in the space of interaction yield shifts in discourse and patterns of association (Scott 1990: 122). Global flows have brought new ideas and tactics to all parties to contention, as with the apparent modularity today of both western-esque 'gay' identity and homophobia, over and/or alongside indigenous presentations of gender, sexuality, and normativity (Bosia and Weiss 2013). And states have ceded sovereignty to capital much as individual workers have been held in its thrall for generations now, as the 'self-regulating market' demanded subordination of society to the requirements of capital (Polanyi 1944).

Among the most intriguing extensions of this necessarily partial survey is to examine the place and potential of truly new democratic forms and spaces. The most celebrated such space now is unquestionably the internet, which offers a platform for voices at all registers, but especially to evaluate and critique 'from below' and in conversation with others, albeit with important limitations. Other spaces are more subtle or specific. For instance, feminist scholars and activists across the region parse the specific nesting of identity categories, in theory and in practice, as with the accommodation or rivalry among intersectional gendered, ethnic, national, and class identities (e.g. Parker et al. 1992). Such investigations query what modes of differentiation are available, how representation should be negotiated, and what rewards and costs are at stake.

The common thread linking these seemingly-disparate efforts is the yen to understand better how democracy plays out on the ground: how a given actor 
or set of actors may (or may not) access the potential for finding community and agency in a nominally liberal polity, at a given point in time and from a particular subject position. Until we understand such processes better, we will not grasp the full scope not just of why regime type matters, but how it matters, for whom, over time. What is clear is that the scope of empowerment extends beyond electoral politics or even policymaking; what happens in the cracks and margins of the regime may matter more for a given individual who feels herself newly acknowledged or empowered to pursue goals outside the state than what 'official' indicators of freedom assess. By that rubric, formal democracy does matter, not least in removing curbs on expression and association, but cultural position, geographic location, and available community may go farther than elite-led institutions to determine how empowered a given citizen feels or is.

\section{Acknowledgements}

Thanks to Xiaoye She for research assistance; to Patricio Abinales, Michael Bosia, EvaLotta Hedman, Paul Hutchcroft, and the journal's reviewers for thoughtful feedback; and to audiences at Stockholm and Sogang universities for their questions and comments on earlier drafts.

\section{References}

Alagappa, Muthiah. 2004. Civil Society and Political Change in Asia: Expanding and Contracting Democratic Space. Stanford, CA: Stanford University Press.

Bellin, Eva. 2000. Contingent democrats: industrialists, labor, and democratization in late-developing countries. World Politics 52, 175-205.

Bernstein, Mary. 1997. Celebration and suppression: the strategic uses of identity by the lesbian and gay movement. American Journal of Sociology 103(3), 531-565.

Bernstein, Mary. 2008. The analytical dimensions of identity: a political identity framework. In Jo Reger, Daniel J. Myers and Rachel L. Einwohner (eds.), Identity Work in Social Movements, pp. 277-301. Minneapolis: University of Minnesota Press.

Bosia, Michael J., and Weiss, Meredith L. 2013. Political homophobia in comparative perspective. In Meredith L. Weiss and Michael J. Bosia (eds.), Global Homophobia: States, Movements, and the Politics of Oppression, pp. 1-29. Champaign, IL: University of Illinois Press.

Boudreau, Vince. 2004. Resisting Dictatorship: Repression and Protest in Southeast Asia. New York: Cambridge University Press.

Buechler, Steven M. 1995. New social movement theories. Sociological Quarterly 36(3), $441-464$.

Caouette, Dominique and Sarah, Turner. 2009. Agrarian Angst and Rural Resistance in Contemporary Southeast Asia. London: Routledge.

Caraway, Teri. 2007. Assembling Women: The Feminization of Global Manufacturing. Ithaca: Cornell University Press. 
Chong, Terence (ed.). 2011. The AWARE Saga: Civil Society and Public Morality in Singapore. Singapore: NUS Press.

Chua Beng Huat (ed.). 2007. Elections as Popular Culture in Asia. New York: Routledge.

Chua Beng Huat. 2011. Making Singapore’s liberal base visible. In Terence Chong (ed.), The AWARE Saga: Civil Society and Public Morality in Singapore, pp. 14-24. Singapore: NUS Press.

Enloe, Cynthia. 2004. The Curious Feminist: Searching for Women in a New Age of Empire. Berkeley, CA: University of California Press.

Fetner, Tina. 2008. How the Religious Right Shaped Lesbian and Gay Activism. Minneapolis: University of Minnesota Press.

Fraser, Nancy. 2003. Rethinking recognition: overcoming displacement and reification in cultural politics. In Barbara Hobson (ed.), Recognition Struggles and Social Movements, pp. 21-32. New York: Cambridge University Press.

Gross, Ames and Connor, Andrew. 2009. Indonesia in the global financial crisis: what HR managers need to know. Society for Human Resources Management HR News, March. Available at: http://www.shrm.org/publications/hrnews/pages/indonesiafinancialcrisis.aspx (accessed on 1 June 2014).

Habermas, Jürgen. 1981. New social movements. Telos 49, 33-37.

Hall-Jones, Peter. 2007. Unionism and Economic Performance. Available at http://www. newunionism.net/library/membercontributions/news/UnionismandEconomicPerformance.htm (accessed on 2 November 2011).

Hedman, Eva-Lotta E. 2001. Contesting state and civil society: Southeast Asian trajectories. Modern Asian Studies 35(4), 921-951.

Heng, Russell Hiang Khng. 2001. Tiptoe out of the closet: the before and after of the increasingly visible gay community in Singapore. Journal of Homosexuality 40(3/ 4), 81-97.

Hobson, Barbara. 2003. Introduction. In Barbara Hobson (ed.), Recognition Struggles and Social Movements, pp. 1-17. New York: Cambridge University Press.

Kaur, Amarjit. 2007. International labour migration in Southeast Asia: governance of migration and women domestic workers. Intersections: Gender, History and Culture in the Asian Context 15. Available at: http://intersections.anu.edu.au/ issue15/kaur.htm (accessed on 1 June 2014).

Kriesi, Hanspeter, Ruud Koopmans, Jan Willem Duyvendak, and Marco, G. Giugni. 1995. New Social Movements in Western Europe. Minneapolis: University of Minnesota Press.

Lawrence, Sophia, and Junko Ishikawa. 2005. Trade Union Membership and Collective Bargaining Coverage: Statistical Concepts, Methods and Findings, Working Paper No. 59. Geneva: International Labour Office.

Liang, Jamison. 2010. Homophobia on the rise. Inside Indonesia 100 (April-June). Available at: http://www.insideindonesia.org/weekly-articles/homophobia-on-therise (accessed on 1 June 2014).

Lim, Merlyna. 2003. From war-net to net-war: the internet and resistance identities in Indonesia. International Information and Library Review 35, 233-248.

McAdam, Doug. 1999 [1982]. Political Process and the Development of Black Insurgency, 1930-1970. Second edition. Chicago: University of Chicago Press.

Melucci, Alberto. 1995. The process of collective identity. In Hank Johnston and Bert Klandermans (eds.), Social Movements and Culture, pp. 41-63. Minneapolis: University of Minnesota Press.

Nevins, Joseph and Peluso, Nancy. 2008. Introduction: commoditization in Southeast Asia. In Joseph Nevins and Nancy Lee Peluso (eds.), Taking Southeast Asia to 
Market: Commodities, Nature, and People in the Neoliberal Age, pp. 1-24. Ithaca, NY: Cornell University Press.

Oetomo, Dédé. 2001. Gay men in the reformasi era. Inside Indonesia 66 (April-June). Available at: http://www.insideindonesia.org/feature-editions/gay-men-in-the-reformasi-era (accessed on 1 June 2014).

Parker, Andrew, Mary Russo, Doris Sommer, and Patricia Yaeger. 1992. Nationalisms and Sexualities. New York: Routledge.

Parreñas, Rhacel Salazar. 2001. Transgressing the nation-state: the partial citizenship and 'imagined (global) community’ of migrant Filipina domestic workers. Signs: Journal of Women in Culture and Society 26(4), 29-54.

Phelan, Shane. 1997. The shape of queer: assimilation and articulation. Women and Politics 18(2), 55-73.

Piper, Nicola, and Anders, Uhlin. 2002. Transnational advocacy networks, female labor migration and trafficking in East and Southeast Asia: a gendered analysis of opportunities and obstacles. Asian and Pacific Migration Journal 11(2), 171-195.

Polanyi, Karl. 1944. The Great Transformation: The Political and Economic Origins of Our Time. Boston: Beacon Press.

Polletta, Francesca, and James, M. Jasper. 2001. Collective identity and social movements. Annual Review of Sociology 27, 283-305.

Rathina Pandi, Asha. 2011. Blogging and Political Mobilisation Among Minority Indians in Malaysia. Unpublished Doctoral Thesis: University of Hawai'i at Manoa.

Rodan, Garry, and Kanishka Jayasuriya. 2009. Capitalist development, regime transitions and new forms of authoritarianism in Asia. The Pacific Review 22(1), 23-47.

Rodriguez, Robyn Magalit. 2008. The labor brokerage state and the globalization of Filipina care workers. Signs: Journal of Women in Culture and Society 33(4), 794-800.

Sanders, Douglas. 2010. The Ang Ladlad Party List: Opening Political Space in the Philippines. ILGA Asia. Available at: http://ilga.org/ilga/en/article/mHAYUOqlnb (accessed on 23 September 2013).

Scott, James C. 1985. Weapons of the Weak: Everyday Forms of Peasant Resistance. New Haven: Yale University Press.

Scott, James C. 1990. Domination and the Arts of Resistance: Hidden Transcripts. New Haven: Yale University Press.

Tilly, Charles. 1978. From Mobilisation to Revolution. Reading, MA: Addison-Wesley.

Weiss, Meredith L. 2005. Who sets social policy in metropolis? Economic positioning and social reform in Singapore. New Political Science 27(3), 267-289.

Weiss, Meredith L. 2006. Rejection as freedom? HIV/AIDS organizations and identity. Perspectives on Politics 4(4), 671-678.

Weiss, Meredith L. 2013. Prejudice before pride: rise of an anticipatory countermovement. In Meredith L. Weiss and Michael J. Bosia (eds.), Global Homophobia: States, Movements, and the Politics of Oppression, pp. 149-173. Champaign, IL: University of Illinois Press.

Weiss, Meredith L., Edward Aspinall and Mark R. Thompson. 2012. Introduction: understanding student activism in Asia. In Meredith L. Weiss and Edward Aspinall (eds.), Student Activism in Asia: Between Protest and Powerlessness, pp. 1-32. Minneapolis: University of Minnesota Press.

Wickramasekera, Piyasiri. 2002. Asian Labour Migration: Issues and Challenges in an Era of Globalization, International Migration Papers \#57. Geneva: International Migration Programme, International Labour Office. 